\title{
Suppresion of Ras Oncogenic Activity by Farnesyl Transferase Inhibitors, YH3938 and $\mathrm{YH} 3945$
}

\author{
Myung-Ju Oh, Nong Yeon Kim, Su-Eun Lim, Young-Hwa Chung and Byung H Jhun* \\ Department of Nanomedical Engineering, Pusan National University, Miryang, Geongnam 727-706, Korea
}

Received November 11, 2009 /Accepted December 3, 2009

\begin{abstract}
Ras genes are responsible for up to $30 \%$ of human tumor mutations and are composed of three isoforms: H-Ras, K-Ras and N-Ras. The post-translational modification of the CAAX motif of the Ras protein is essential in Ras actions. In the present study, we studied the effects of novel farnesyl transferase inhibitors (FTIs), YH3938 and YH3945, on the actions of oncogenic mutants of H-Ras, K-Ras and N-Ras. YH3938 and YH3945 completely reverted the proliferation and morphology of oncogenic H-Ras-transformed Rat2 cells, but not of oncogenic K-Ras-transformed Rat2 cells. Oncogenic N-Rastransformed Rat2 cells were slightly affected. Activation of SRE promoters by oncogenic H-Ras and N-Ras, but not by K-Ras, were inhibited by treatment with YH3938 and YH3945. Using bandshift analysis, YH3938 suppressed the processing of oncogenic H-Ras and N-Ras, but not that of oncogenic K-Ras protein. YH3945 only inhibited the processing of H-Ras. From these results, we conclude that YH3938 and YH3945 specifically inhibit actions of oncogenic H-Ras through inhibition of its farnesylation, that YH3938 also inhibits N-Ras activity in a dose-dependent manner, and that these drugs have no effect on oncogenic K-Ras activity.
\end{abstract}

Key words : Ras, farnesyl transferase, proliferation, SRE promoter

\section{서 론}

ras 유전자는 인간의 암과 관련하여 발견된 최초의 암유전자 이며, 또한 Ras는 세포 외부 자극에 의해 발생하는 세포내의 $\mathrm{DNA}$ 합성, 세포분화, 세포 골격 변화, 세포 이동 등의 조절 신 호의 중요한 분자 switch 단백질로 작용하고 있다 $[5,17,22]$. 구 조적으로 유사한 H-ras, K-ras, N-ras와 같이 세 종류의 isoform 이 존재하며 이 ras 유전자의 변이가 암환자의 $30 \%$ 에서 발견된 다[8,9]. 특히 $12,13,61$ 번 위치의 아미노산에서 변이가 자주 발견된다. Ras isoform별로 발생하는 암 종류나 빈도가 상이한 데 H-ras의 변이는 주로 갑상선암, 방광암이나 신장암에서 발 견되며 K-ras의 변이는 췌장암, 폐암, 대장암에서 발견되고 N-ras의 변이는 골수암이나 임파암 등에서 주로 발견된다[17].

Ras의 활성화에는 번역후 변형(post-translational modification)이 중요하다. Ras의 정상적인 기능을 위해서는 단백 질로 합성된 후 세포질과 endoplasmic reticulum (ER)에서 번 역후 변형이 일어나서 세포막의 안쪽막에 삽입되어야 한다[7]. Ras는 C-말단 부분에 CAAX (C, cysteine; A, aliphatic amino acid; X, any amino acid) motif를 가지는데 여기에 세 종류의 변형이 연속적으로 일어나게 된다: 1) cysteine 잔기의 prenylation, 2) 아미노산 AAX의 proteolytic cleavage, 3) prenylatn, cysteine의 methyl기 도입이 순차적으로 일어난다. 첫

*Corresponding author

Tel : +82-55-350-5291, Fax : +82-55-350-5653

E-mail : bjhun@pusan.ac.kr
번째 단계인 Ras단백질의 prenylation이 가장 중요한데, 이 과정은 C-말단에 존재하는 CAAX motif 종류에 따라 cysteine 잔기에 farnesyl기 또는 geranylgeranyl기가 공유 결합된다 $[10,12]$. 이 prenylation은 farnesyl transferase (FTase)와 geranylgeranyl transferase (GGTase)에 의해 일어난다[4].

발암원성 Ras 활성에 번역후 변형이 반드시 필요하다는 사 실이 알려지면서 이 기전을 억제하여 항암제로 개발하기 위해 많은 연구가 진행되고 있다[24]. Ras의 번역후 변형 중 첫번째 단계인 prenylation이 rate-limiting step이며 발암원성 Ras가 세포의 형질전환에 필수적이라는 것이 알려져 이 prenylation 에 관여하는 효소인 FTase나 GGTase를 억제하는 약물이 항암 제 개발의 목표가 되었다[2,11]. CAAX motif나 isoprenoid의 구조 유사성에 기초하여 새로운 화합물을 합성하거나, 천연물 library를 이용하여 FTase를 이용한 효소활성 측정법을 이용 한 high throughput screening을 통해 발견하는 방법이 사용 되고 있다. 많은 종류의 prenylation 억제제들이 개발되었고, 현재 몇 가지 후보 물질들은 항암 효과를 관찰한 임상실험 중에 있다[1,14].

본 연구에서는 유한양행의 신약개발연구실에서 CAAX motif중 Cys-Ile-Ile-Met을 template peptide로서 사용하여 다 양한 유도체들을 합성하여 FTase 억제 효과를 in vitro 상에서 screening하여 선택된 YH3938과 YH3945을 본 연구에 사용하 였다. 발암원성 Ras 유전자를 isoform별로 발현하는 세포주에 서 YH3938과 YH3945의 세포증식과 세포형태에 대한 영향을 검토하여 효과가 있음을 조사하였고, 또한 분자적 기전을 밝 히기 위해 SRE promoter 활성화에 대한 영향과 Ras 단백질의 
prenylation을 조사하여 YH3938과 YH3945의 작용기전을 규 명하였다.

\section{재료 및 방법}

\section{재료}

세포 배양을 위한 Dulbecco's modified Eagle medium (DMEM) 배지, fetal bovine serum (FBS) 및 기타 세포 배양에 사용된 다른 시약들은 Gibco-BRL사(Gaithersburg, MD, USA) 로부터 구입하여 사용하였다. $\cos 7$ 에 유전자를 이입하여 사용 하기 위해서는 Qiagen사(Hilden, Germany)의 SuperFect를 사용하였다. MTT assay 킷트는 Roche사(Mannheim, Germany)의 제품을 사용하였고, Luciferase assay를 위한 시 약들은 Promega사(Madison, WI, USA)의 제품을 사용하였다. YH3938 및 YH3945는 CAAX motif중 Cys-Ile-Ile-Met을 template peptide로서 사용하여 유한양행에서 합성한 것을 제공 받아 DMSO에 녹여 사용하였다. Immunoblotting용 nitocellulose membrane은 Schleicher \& Schuell사(NH, USA)의 것을 사용하였고 enhanced chemiluminescence (ECL) 킷트와 Horseradish peroxidase가 붙어있는 mouse IgG는 Amersham Pharmacia Biotech (Uppsala, Sweden) 것을 사용하였다. Anti-pan-Ras antibody는 Calbiochem (San Diego, CA, USA) 에서 구입하였다.

\section{세포배양}

Rat2세포에 MV7 control plasmid, MV7-H-RasV12, MV7K-RasV12, MV7-N-RasN12로 형질전환시킨 세포(Rat2, Rat2H-Ras, Rat2-K-Ras, Rat2-N-Ras)는 Dr. Pai (Schering-Plough 연구소, Kenilworth, NJ, USA)로부터 제공받았으며, 각 세포 의 배양은 DMEM ( $10 \% \mathrm{FBS}, 4 \mathrm{mM}$ L-glutamine, $10 \mu \mathrm{g} / \mathrm{ml}$ gentamicin, $1 \mathrm{mM}$ non-essential amino acid, $200 \mu \mathrm{g} / \mathrm{ml}$ geneticin 포함)에서 배양하였다. $\cos 7$ 세포는 American Type Culture Collection (Rockville, Maryland, USA)에서 구입하여 배양하였다.

\section{MTT assay}

Rat2, Rat2-H/K/N-Ras를 well당 배지의 부피가 $100 \mu 1$ 가 되도록 하여 96 well에서 24시간 배양한 후 YH3938 및 YH3945를 지시된 농도가 되도록 처리하였다. 5일 후에 MTT assay를 킷트 제조회사의 지시에 따라 실시하였다. 간단히 설 명하면, $10 \mu \mathrm{l}$ 의 MTT labeling reagent (최종농도 $0.5 \mathrm{mg} / \mathrm{ml}$ ) 를 각각의 well에 가한 후 $37^{\circ} \mathrm{C}, 0.5 \% \mathrm{CO}_{2}$ 조건에서 4 시간 배양하였다. 그 후에 각각의 well에 $100 \mu \mathrm{l}$ 의 solubilization solution을 가하여 $37^{\circ} \mathrm{C}, 0.5 \% \mathrm{CO}_{2}$ 조건에서 16 시간 동안 배양 하였다. 생성된 formazan의 흡광도를 $570 \mathrm{~nm}$ 에서 plate read$\mathrm{er}$ 를 이용하여 측정하였다.

\section{세포 모양 관찰과 Western blotting}

세포의 모양을 비교하기 위하여 각각의 세포를 6 well에서 24시간 배양한 후 DMSO에 녹인 YH3938 및 YH3945가 최종 농도가 $0.1 \mu \mathrm{M}, 1 \mu \mathrm{M}$ 이 되도록 $\mathrm{DMSO}$ 로 농도를 조절하여 처 리한 후 계속 관찰하면서 5 일 후에 사진을 찍었다. 그 후에 세포를 ice-cold PBS로 한 번 세척한 후에 RIPA buffer 250 $\mu 1$ 에 녹였다. 단백질의 양을 측정하여 약 $10 \mu \mathrm{g}$ 의 cell lysate를 sample buffer에 녹여 $14 \%$ 의 sodium dodecyl sulfate polyacrylamide gel (SDS-PAGE)로 전기영동하여 단백질 분리 후, anti-pan-Ras antibody를 2\% skim milk/TTBS에 1:400으로 희 석하여 immunoblotting을 수행하고 ECL 킷트를 이용하여 확 인하였다.

\section{Plasmid 제작, Transfection, SRE promoter assay}

발암원성 H-rasV12, K-rasV12, N-rasN12, H-rasV12-CVLL 들의 $\mathrm{cDNA}$ 들은 $\mathrm{N}$-말단부위에 $\mathrm{HA} \operatorname{tag}$ 를 첨가하기 위해 XbaI, BamHI site를 이용하여 mammalian expression vector 인 pCGN에 subcloning하였다. 이 실험을 위해 PCR을 통해 subcloning된 모든 cDNA들은 염기배열을 통해 확인하였다.

$\operatorname{Cos} 7$ 세포에 이들 plasmid를 transfection하기 위해 12-well plate에 $0.8 \times 10^{5}$ 세포를 넣고 24 시간 배양하였다. SRE-Luc의 reporter vector $50 \mathrm{ng}$ 과 pCGN에 삽입된 ras 유전자 각 100 $\mathrm{ng}$ 을 SuperFect를 이용하여 3시간 배양하고 starvation용 $\mathrm{DMEM}$ 으로 갈아주었다. FTI에 의한 영향을 살펴보기 위해서 는 DMSO 또는 YH3938 및 YH3945이 포함된 starvation용 DMEM으로 갈아주었다. 20시간 후에 세포를 $250 \mu 1$ 의 reporter lysis buffer로 녹인 후 원심분리하고 그 상등액 $10 \mu \mathrm{l}$ 를 luciferrin $50 \mu \mathrm{l}$ 와 섞어서 luminometer (Tuner Designs Instruments, CA, USA)로 측정하여 luciferase의 활성을 측정 하였다.

\section{결 과}

Farnesyl transferase 억제제인 YH3938 및 $\quad$ YH3945 가 발암원성 Ras에 의한 세포의 증식에 미치는 영향

Rat2에 발암원성 H-rasV12, K-rasBV12, N-rasN12의 유전자 가 삽입된 plasmid를 도입시켜 형질전환시킨 세포주를 사용 하여 YH3938 및 YH3945가 형질전환된 세포의 증식에 미치는 영향을 조사하였다. 먼저 YH3938이 미치는 영향을 살펴보면, Rat2-H-Ras의 증식은 농도 의존적으로 억제되었다(Fig. 1A). $1 \mu \mathrm{M}$ 의 YH3938에 의해 Rat2-H-Ras는 약 $68 \%$ 정도 증식이 억제되었다. $\mathrm{ED}_{50}$ 은 약 $30 \mathrm{nM}$ 로써 보고된 다른 $\mathrm{FTI}$ 에 비해 높은 efficacy를 보였다. 반면에 정상적인 Rat2와 Rat2-K-Ras 의 증식에 거의 영향을 주지 않았다. Rat2-N-Ras의 경우도 0.5 $\mu \mathrm{M}$ 의 농도까지는 거의 영향을 받지 않으나 $1 \mu \mathrm{M}$ 의 $\mathrm{YH} 3938$ 에 의해 약 $40 \%$ 가량 증식이 억제되었다. 따라서 YH3938은 정상 
(A)

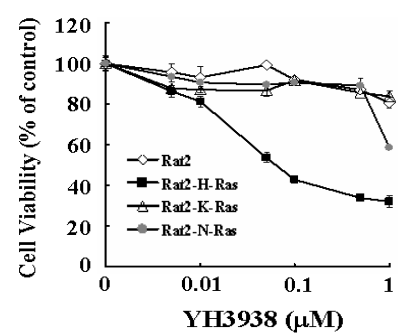

(B)

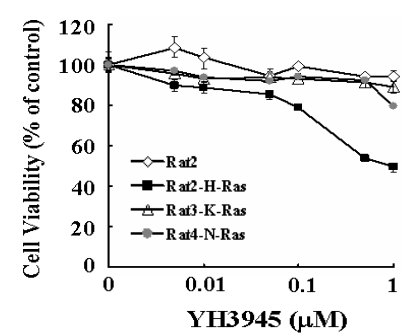

Fig. 1. Effects of YH3938 and YH3945 on proliferation of Rastransformed Rat2 cells. Rat2, Rat2-H-Ras, Rat2-K-Ras and Rat2-N-Ras cells were grown in 96-well plate for $24 \mathrm{hr}$ and treated with the indicated concentrations of YH3938 (A) or YH3945 (B) for 5 days. The cell proliferation was determined by MTT assay as described in the "Experimental Procedures". Values represents mean \pm S.E. of two experiments carried out in triplicate.

세포의 세포증식에는 거의 영향을 미치지 않으나 H-RasV12 에 의해 형질전환된 세포의 증식을 선택적으로 억제함을 알 수 있었다. 또한 YH3945에 의한 영향을 살펴보면, Rat2-H-Ras 의 증식은 농도 의존적으로 억제되었다(Fig. 1B). 그러나 정상 적인 Rat2와 Rat2-K-Ras의 증식에 거의 영향을 주지 않았으며, Rat2-N-Ras에는 YH3938과는 달리 세포증식에는 큰 영향이 없음을 알 수 있었다. 이상의 결과로부터 YH3938과 YH3945 가 선택적으로 발암원성 H-Ras, K-Ras, N-Ras에 의해 형질전 환된 세포의 증식에 효과가 있다는 것을 알 수 있었다.

Farnesyl transferase 억제제인 YH3938 및 YH3945 가 발암원성 Ras에 의한 세포의 형태에 미치는 영향

다음으로 이들 Rat2, Rat2-H-Ras, Rat2-K-Ras, Rat2-N-Ras 세포 형태에 대한 YH3938 및 YH3945의 영향을 조사하였다. Fig. 2에서 보는 바와 같이, 정상 섬유아세포의 성장은 세포의 접촉에 의해 세포증식이 억제되어 전형적인 형태인 편평하고 단층의 형태로 관찰되었다. 그러나 발암원성 $\mathrm{ras}$ 의 유전자를 넣어 형질전환시킨 세포들에서는 세포의 접촉에 의한 억제가 관찰되지 않았고 다른 세포 위에 또 다른 세포가 겹쳐 자라는 전형적인 형질전환된 세포의 형태를 나타내었다.

이어 YH3938 및 YH3945의 영향을 살펴보면, Rat2-H-Ras의 세포는 YH3938 및 $\mathrm{YH} 3945$ 저농도인 $0.1 \mu \mathrm{M}$ 에서도 겹쳐자라 는 세포가 거의 관찰되지 않았고 대조군인 Rat2와 유사한 정 상적인 세포 형태로 바뀐 것을 알 수 있었다. 반면에 Rat2-KRas, Rat2-N-Ras의 모양에는 거의 영향이 없었다. 그러나 고농 도인 $1.0 \mu \mathrm{M}$ 로 처리한 경우에는 $\mathrm{YH} 3938$ 에서는 Rat2-H-Ras와 Rat2-N-Ras에서 효과가 있어 세포 형태가 정상화되었으나, 역 시 Rat2-K-Ras에는 아무런 영향이 없었다. 그러나 YH3945는 YH3938과는 달리 Rat2-N-Ras에 약한 정도의 효과만 지닌다 는 것을 알 수 있었다. 이러한 결과는 YH3938과 YH3945가 발암원성 Ras에 의한 세포 형태 변화에 Ras isoform을 선택적

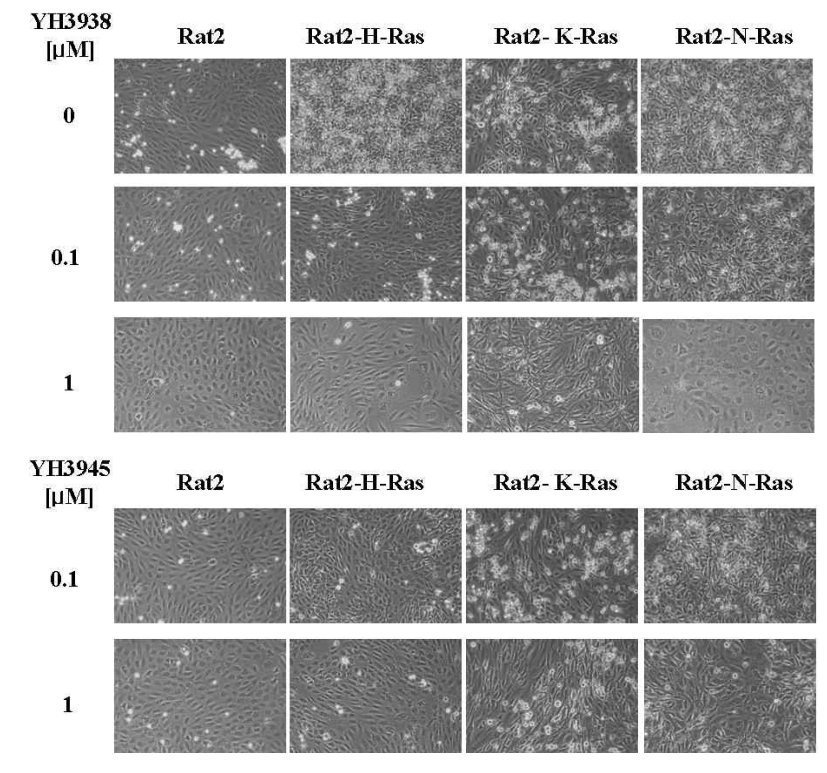

Fig. 2. YH3938 and YH3945 reverted morphology of Rat2-H-Ras and Rat2-N-Ras, but not Rat2-K-Ras. Rat2, Rat2-H-Ras, Rat2-K-Ras and Rat2-N-Ras cells were grown in 6-well plate for $24 \mathrm{hr}$ and treated with DMSO or $0.1 \mathrm{mM}$ or $1 \mathrm{mM}$ of YH3938 (upper panel) or YH3945 (lower panel). After 5 days, the morphology were compared under the microscope.

으로 농도의존적으로 억제하는 효과가 있음을 알 수 있었다.

YH3938 및 $\mathrm{YH} 3945$ 가 Ras에 의한 SRE promoter 활 성화에 미치는 영향

Ras는 세포내에서 여러 신호전달 경로들을 통해 신호를 전 달하여 oncogenesis에 관계되는 유전자의 발현을 조절하는 전 사인자들의 발현을 조절하여 최종적으로 세포증식을 유도한 다[18]. 이들 전사인자들의 활성은 promoter 영역에 있는 Response Element의 활성화에 의해 조절된다. 이들 Response Element 중 대표적인 Serum Response Element (SRE)가 발암 원성 Ras에 의해 활성화된다고 잘 알려져 있는데, 이에 대한 $\mathrm{YH} 3938$ 과 YH3945의 영향을 살펴보기로 하였다. Cos7 세포에 발암원성 $r a s$ 의 유전자와 pSRE-Luc vector와 같이 transfection하고 luciferase 활성 유도를 측정하여 SRE promoter 활성화 정도를 관찰하고 $\mathrm{YH} 3938$ 및 $\mathrm{YH} 3945$ 가 미치는 영향을 관찰하였다. 발암원성 $\mathrm{H}-, \mathrm{K}-, \mathrm{N}-\mathrm{Ras}$ 에 의해 SRE promoter 활성화가 증가되었는데, 이 활성화가 $\mathrm{YH} 3938$ 과 $\mathrm{YH} 3945$ 에 의 해 선택적으로 억제되었다(Fig. 3). H-Ras에 의한 SRE promoter 활성화는 $\mathrm{YH} 3938$ 와 $\mathrm{YH} 3945$ 에 의해 강하게 억제되었 으나, 반면에 K-Ras에 의한 SRE promoter 활성화에는 억제효 과가 없었다. N-Ras의 경우에는 $\mathrm{YH} 3938$ 에 의해서는 강하게 억제되었으나, YH3945에 의해서는 약하게 억제되는 것을 알 수 있었다. 따라서 YH3938과 YH3945가 발암원성 Ras에 의한 SRE promoter 활성화 유도 기전에 작용하여 Ras에 의한 세포 


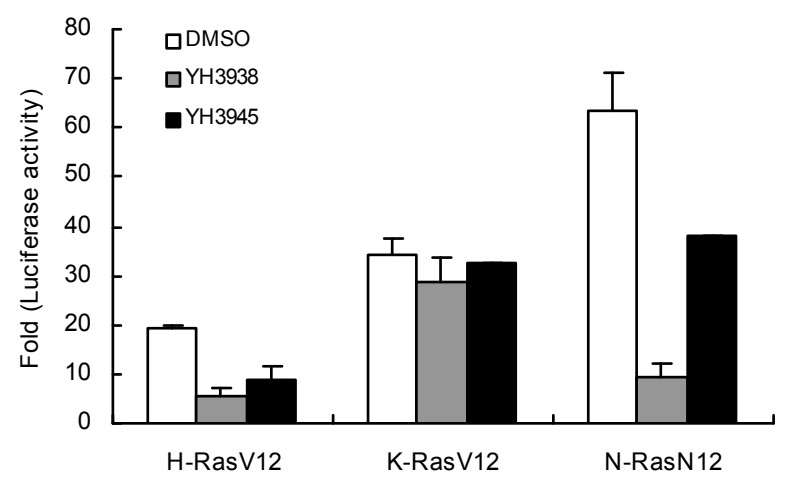

Fig. 3. Effect of $\mathrm{YH} 3938$ and $\mathrm{YH} 3945$ on SRE activation induced by oncogenic $\mathrm{H} / \mathrm{K} / \mathrm{N}$-Ras in Cos7 cells. Cos7 cells were grown on 12-well plate and cotransfected with either pCGN-H-rasV12 or K-rasV12 or N-rasN12 DNA (100 ng) plus pSRE-Luc reporter DNA (50 ng). After $4 \mathrm{hr}$, the transfected cells were serum-starved in the presence of DMSO or $1 \mathrm{mM}$ of YH3938 and YH3945 for $20 \mathrm{hr}$. Luciferase activity was determined as described under "Experimental Procedures". Values represents mean \pm S.E. of three experiments.

증식 억제 효과를 나타내는 것으로 사료된다.

\section{YH3938 및 YH3945의 Ras prenylation에 대한 영향}

다음으로 $\mathrm{YH} 3938$ 과 $\mathrm{YH} 3945$ 의 작용이 Ras 단백질의 번역 후 변형에 대한 영향을 조사하였다. 세포 증식이나 모양의 변 화를 관찰한 조건과 같이 형질전환된 Rat2 세포들를 배양 및 처리한 후, anti-pan-Ras antibody로 immunoblotting하여 Ras 단백질의 bandshift를 조사하였다. Ras prenylation이 억제되 면 Ras band가 위로 shift하게 되는데, Fig. $4 \mathrm{~A}$ 에서 보는 바와 같이 YH3938에 의해 Rat2-H-RasV12 세포와 Rat2-N-Ras 세포 의 Ras 단백질 band가 shift되는 것이 관찰되었다. 즉 YH3938 에 의해 H-Ras와 N-Ras의 prenylation이 억제되었음을 알 수 있다. 그러나 K-Ras의 prenylation에는 YH3938이 영향을 끼 치지 않음을 알 수 있었다. YH3945의 경우에는 H-Ras에만 영향이 있었다. 흥미롭게도 Fig. $4 \mathrm{~A}$ 에서 약물을 처리하면 K-Ras나 N-Ras의 단백질양이 bandshift와는 별도로 감소하는 것이 관찰되었다. 이 단백질 양의 감소를 조사하기 위해 대조 군으로 GAPDH 항체로 immunoblotting하여 살펴본 결과, 전 기영동 시 loading한 단백질의 양은 동일하다는 것을 알 수 있었다. 즉 세포독성 등에 의한 세포 감소가 아닌 아직 모르는 기전에 의한 K-Ras나 N-Ras 특이적인 합성이 억제되거나, 분 해 속도의 증가로 인해 발생하는 것으로 추정된다.

Ras단백질의 prenylation은 farnesylation과 geranygeranylation이 일어날 수 있는데, 보고에 따르면 K-Ras나 N-Ras의 경 우 Farnesyl transferase 억제제 존재 하에서 farnesylation이 억제된 반면 대신에 geranylgeranylation이 일어난다는 것이 알려졌다. 따라서 YH3938과 YH3945이 geranylgeranylation
(A)

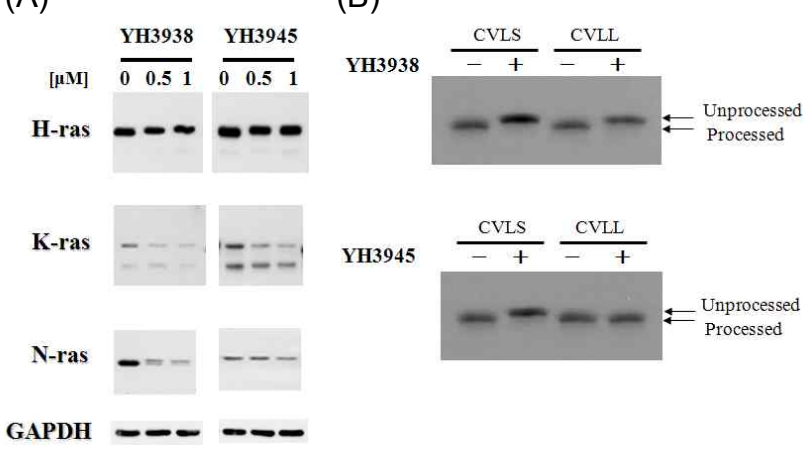

Fig. 4. Effects of $\mathrm{YH} 3938$ and $\mathrm{YH} 3945$ on prenylation of Ras protein. (A) Rat2-H-Ras, Rat2-K-Ras and Rat2-N-Ras cells were grown in 6-well plate for 3 days and treated with DMSO or $0.5 \mathrm{mM}$ or $1 \mathrm{mM}$ of YH3938 or YH3945. The cells then were lysed with RIPA buffer and subjected to $14 \%$ SDS-PAGE followed by immunoblotting with anti-Pan-Ras antibody. (B) Cos7 cells were grown in 12-well plates and transfected with either wild type pCGN-H-rasV12 (CVLS) or mutant pCGN-H-RasV12CVLL (CVLL). After 1 day, the cells were treated with $1.0 \mathrm{mM}$ of YH3938 or YH3945 for $24 \mathrm{hr}$, and the lysates were immunoblotted with anti-pan-Ras antibody.

을 억제하는 지를 알기위해 H-Ras의 CAAX motif을 geranylgeranylation만 일어나는 CVLL로 바꾸어 bandshift를 조 사하였다. H-Ras-CVLL mutant를 Cos7 세포에 transfection하 고 Ras 단백질의 bandshift에 대한 $\mathrm{YH} 3938$ 의 영향을 조사하 였다. Fig. $4 \mathrm{~B}$ 에서 보는 것처럼 wild type H-Ras-CVLS는 YH3938과 YH3945에 의해 prenylation이 억제되어 bandshift 가 나타났다. Mutant H-Ras-CVLL의 경우에, YH3938에 의해 prenylation이 억제되어 bandshift가 나타났으나, YH3945에 의해서는 효과가 없었다. 이상의 결과로부터 YH3938은 Ras의 prenylation인 farnesylation 뿐 아니라 geranylgeranylation도 억제한다는 것을 알 수 있었다. 반면 YH3945는 farnesylation 만 억제한다는 것을 알 수 있었다.

\section{고 찰}

본 연구에서는 farnesyl transfease 억제제인 YH3938과 YH3945가 세포내에서 발암성 Ras에 의한 세포 증식억제 효과 를 isoform 특이적인 영향을 조사하였다. H-Ras에 의한 세포 증식을 억제하였으나, N-ras에 의한 효과는 농도의존적으로 효과가 나타나는 것을 알 수 있었고, K-Ras에는 아무런 영향이 없었다. 또한 H-, N-Ras로 형질 변환된 세포의 morphology를 정상적으로 환원시켰고, $\mathrm{H}-, \mathrm{N}-\mathrm{Ras}$ 에 의한 SRE promoter 활 성 유도를 억제하였다. 그러나 예상한 바와 같이 K-Ras 경우 억제효과가 보이지 않았다. 이러한 YH3938과 YH3945 효과는 $\mathrm{H}, \mathrm{N}-\mathrm{Ras}$ 의 prenylation의 억제를 통하여 일어나는 것으로 밝 
혀졌다.

ras 유전자는 인간 암의 $30 \%$ 이상에서 변이가 발생하며, 또한 동물의 실험적인 암 모델에서도 자주 변이가 발견된다 [8,17]. 그리고 Ras isoform별로 발생하는 암 종류나 빈도가 상이한데 이러한 isoform별 발암조직의 차이점에 관해서는 아 직 잘 모르고 있지만 이러한 것들은 Ras의 각 isoform별 기능 상의 차이와 관련이 있을 것으로 추정된다. FTase 억제제인 YH3938이나 YH3945가 Ras isoform별로 형질전환된 Rat2 세 포에서 다른 억제 작용이 나타난 것을 관찰하였다. 따라서 이 들 약물들이 Ras isoform별로 발생한 암의 특이적인 치료제로 사용될 수 있다는 것을 시사해 준다.

H-Ras, K-Ras, N-Ras는 189개의 아미노산으로 구성되어있 고, 처음 164 개의 아미노산 종류와 배열순서는 유사하나 165 번부터 C-말단까지는 다양한 아미노산 배열을 가진다[5,16]. 이 165 번부터 185 번까지를 hypervariable region (혹은 heterogenous region)이라 부르고 특히 C-말단에는 CAAX motif 가 존재한다. Ras isoform별 CAAX motif의 배열은 CVLS (H-Ras), CVIM (K-Ras), CVVM (N-Ras) 등이다. 이 잔기에 번역 후 변형의 첫 번째 단계인 prenylation이 일어나 Ras 단 백질의 활성을 결정하게 된다[24]. H-Ras의 경우에는 항상 farnesylation이 발생하며, K-Ras와 N-Ras는 farnesylation이나 geranylgeranylation이 일어날 수 있다. 특히 FTase 억제제가 존재하는 경우 farneyslation이 억제되고 geranylgeranylation 이 일어난다[23]. 즉 K-Ras와 N-Ras는 FTase에 대해 높은 결합 력을 지니지만 GGTase에 대해서도 결합력을 지녔기 때문에 FTase 억제제가 존재할 경우 K-Ras나 N-Ras는 geranylgeranylation이 발생하여 발암원성 Ras에 의한 세포 증식이나 세 포형태 변형과 같은 암세포 특유의 성질을 나타내는 것으로 보여진다. 흥미롭게도 $\mathrm{YH} 3938$ 은 FTase 뿐만이 아니라 GGTase에 의한 prenylation도 억제하는데(Fig. 4B), N-Ras에 의한 발암원성은 억제하지만, K-Ras에 의한 발암원성은 억제 할 수가 없었다. 이는 K-Ras에 대한 GGTase의 결합력이 $\mathrm{N}-\mathrm{Ras}$ 에 비해 상당히 높아 $\mathrm{YH} 3938$ 에 의해 K-Ras의 prenylation을 억제할 수 없는 것으로 추정된다. 이러한 YH3938 과 YH3945의 isoform 특이적인 작용은 향후 더욱 많은 연구가 필요한 것으로 사료된다.

FTase 억제제가 in vitro와 in vivo에서 암세포의 성장을 억 제하는 것이 보고되어 있다[3,19]. FTase 억제제에 의해 인간암 세포가 G2-M phase에 축적되는데, 이는 p53의존적인 p21waf /cip1 유도와 관련이 있다. 훙미롭게도 FTase 억제제가 발암 원성 K-Ras에 의한 폐암세포의 증식도 억제하였다[15]. 이는 Ras이외에 세포내 다른 단백질의 farnesylation을 억제하여 암 세포증식을 억제하는 것으로 밝혔졌다. 이러한 FTase 억제제 의 표적이 되는 단백질에는 RhoB, Rheb, HIF-1alpha, CENP-E, CENP-F, insulin-like growth factor (IGF)-binding protein-3, heat shock protein 90, 뇌에 많이 존재하는 Ras 동
족체, 그리고 아직 밝혀지지 않은 단백질 등이 있다[6,13, 20,21]. 따라서 본 연구에서 사용한 YH3938과 YH3945는 FTase에 특이적인 억제 효과를 보였는데, 이들 단백질에도 farnesylation을 억제하는지 검토하는 것은 흥미로운 실험이 될 것이다.

결론적으로, $\mathrm{YH} 3938$ 과 $\mathrm{YH} 3945$ 가 발암원성 $\mathrm{H}-\mathrm{Ras}$ 에 의한 세포증식, 세포변형과 신호전달은 확실하게 억제하나, K-Ras 에는 전혀 영향이 없음을 알 수 있었다. N-ras의 경우 YH3938 은 효과가 있으나, YH3945는 미약한 영향이 있음을 알 수 있 었다. 이러한 효과는 이들 억제제들이 직접적으로 Ras단백질 의 prenylation 효소에 작용하여 일어나는 것으로 보여진다. 따라서 본 연구에 사용한 FTase 억제제들이 H-ras와 일부 N-ras에 의한 암에는 효과적인 항암제가 될 수 있을 것으로 사료된다.

\section{감사의 글}

본 연구는 부산대학교의 연구 지원에 의한 결과이며 이에 감사드립니다.

\section{References}

1. Adjei, A. A., C. Erlichman, J. N. Davis, D. L. Cutler, J. A. Sloan, R. S. Marks, L. J. Hanson, P. A. Svingen, P. Atherton, W. R. Bishop, P. Kirschmeier, and S. H. Kaufmann. 2000. A Phase I trial of the farnesyl transferase inhibitor SCH66336: evidence for biological and clinical activity. Cancer Res. 60, 1871-1877.

2. Agrawal, A. G. and R. R. Somani. 2009. Farnesyltransferase inhibitor as anticancer agent. Mini Rev. Med Chem 9, 638-652.

3. Ashar, H. R., L. James, K. Gray, D. Carr, M. McGuirk, E. Maxwell, S. Black, L. Armstrong, R. J. Doll, A. G. Taveras, W. R. Bishop, and P. Kirschmeier. 2001. The farnesyl transferase inhibitor SCH 66336 induces a G(2) --> M or G(1) pause in sensitive human tumor cell lines. Exp. Cell Res. $262,17-27$.

4. Ashby, M. N. 1998. CaaX converting enzymes. Curr. Opin. Lipidol. 9, 99-102.

5. Barbacid, M. 1987. Ras genes. Annu. Rev. Biochem 56, 779-827.

6. Basso, A. D., A. Mirza, G. Liu, B. J. Long, W. R. Bishop, and P. Kirschmeier. 2005. The farnesyl transferase inhibitor (FTI) SCH66336 (lonafarnib) inhibits Rheb farnesylation and mTOR signaling. Role in FTI enhancement of taxane and tamoxifen anti-tumor activity. J. Biol. Chem 280, 3110131108.

7. Basso, A. D., P. Kirschmeier, and W. R. Bishop. 2006. Lipid posttranslational modifications. Farnesyl transferase inhibitors. J. Lipid Res. 47, 15-31.

8. Bos, J. L. 1989. Ras oncogenes in human cancer: a review. 
Cancer Res. 49, 4682-4689.

9. Bourne, H. R., D. A. Sanders, and F. McCormick. 1990. The GTPase superfamily: a conserved switch for diverse cell functions. Nature 348, 125-132.

10. Chiu, V. K., T. Bivona, A. Hach, J. B. Sajous, J. Silletti, H. Wiener, R. L. 2nd. Johnson, A. D. Cox, and M. R. Philips. 2002. RAS signalling on the endoplasmic reticulum and the Golgi. Nat. Cell Biol. 4, 343-350.

11. Gibbs, J. B., A. Oliff, and N. E. Kohl. 1994. Farnesyltransferase inhibitors: Ras research yields a potential cancer therapeutic. Cell 77, 175-178.

12. Glomset, J. A. and C. C. Farnsworth. 1994. Role of protein modification reactions in programming interactions between RAS-related GTPases and cell membranes. Annu. Rev. Cell Biol. 10, 181-205.

13. Han, J. Y., S. H. Oh, F. Morgillo, J. N. Myers, E. Kim, W. K. Hong, and H. Y. Lee. 2005. Hypoxia-inducible factor 1a and antiangiogenic activity of farnesyltransferase inhibitor SCH66336 in human aerodigestive tract cancer. J. Natl. Cancer Inst. 97, 1272-1286.

14. Hanrahan, E. O., M. S. Kies, B. S. Glisson, F. R. Khuri, L. Feng, H. T. Tran, L. E. Ginsberg, M. T. Truong, W. K. Hong, and E. S. Kim. 2009. A phase II study of Lonafarnib (SCH66336) in patients with chemorefractory, advanced squamous cell carcinoma of the head and neck. Am J. Clin. Oncol. 32, 274-279.

15. Lantry, L. E., Z. Zhang, R. Yao, K. A. Crist, Y. Wang, J. Ohkanda, A. D. Hamilton, S. M. Sebti, R. A. Lubet, and M. You. 2000. Effect of farnesyltransferase inhibitor FTI-276 on established lung adenomas from A/J mice induced by 4(methylnitrosamino)-1-(3-pyridyl)-1-butanone. Carcinogenesis 21, 113-116.

16. Lowy, D. R. and B. M. Willumsen. 1993. Function and regu- lation of ras. Annu Rev. Biochem 62, 851-891.

17. Malumbres, M. and M. Barbacid. 2003. RAS oncogenes: the first 30 years. Nat. Rev. Cancer 3, 459-465.

18. Mayo, M. W., C. Y. Wang, P. C. Cogswell, K. S. RogersGraham, S. W. Lowe, C. J. Der, and A. S. Jr. Baldwin. 1997. Requirement of NF-kappaB activation to suppress p53-independent apoptosis induced by oncogenic Ras. Science 278, 1812-1815.

19. Nagasu, T., K. Yoshimatsu, C. Rowell, M. D. Lewis, and A. M. Garcia. 1995. Inhibition of human tumor xenograft growth by treatment with the farnesyl transferase inhibitor B956. Cancer Res. 55, 5310-5314.

20. O'Regan, R. M. and F. R. Khuri. 2004. Farnesyl transferase inhibitors: the next targeted therapies for breast cancer? Endocr. Relat. Cancer 11, 191-205.

21. Oh, S. H., W. Y. Kim, J. H. Kim, M. N. Younes, A. K. El-Naggar, J. N. Myers, M. Kies, P. Cohen, F. Khuri, W. K. Hong, and H. Y. Lee. 2006. Identification of insulin-like growth factor binding protein-3 as a farnesyl transferase inhibitor SCH66336-induced negative regulator of angiogenesis in head and neck squamous cell carcinoma. Clin. Cancer Res. 12, 653-661.

22. Satoh, T., M. Nakafuku, and Y. Kaziro. 1992. Function of Ras as a molecular switch in signal transduction. J. Biol. Chem 267, 24149-24152.

23. Whyte, D. B., P. Kirschmeier, T. N. Hockenberry, I. Nunez-Oliva, L. James, J. J. Catino, W. R. Bishop, and J. K. Pai. 1997. K- and N-Ras are geranylgeranylated in cells treated with farnesyl protein transferase inhibitors. J. Biol. Chem 272, 14459-14464.

24. Winter-Vann, A. M. and P. J. Casey. 2005. Post-prenylation-processing enzymes as new targets in oncogenesis. Nature Rev. Cancer 5, 405-412.

\section{초록 : Farnesyl transferase 억제제인 YH3938 및 YH3945에 의한 Ras 발암원성 억제}

오명주 · 김농연 · 임수은 · 정영화 · 전병학*

(부산대학교 나노메디컬공학과)

Ras 유전자는 30\%의 인간암에서 변이가 발견되며 세 종류의 isoform, H-Ras, K-Ras 및 N-Ras로 구성되어 있 다. Ras 단백질의 CAAX motif에 farnesylation과 같은 번역 후 변형은 Ras의 활성에 필수 요소이다. 본 연구에서 는 새로운 farnesyl transferase 억제제인 YH3938과 YH3945의 발암원성 H-Ras, K-Ras 및 N-Ras의 작용에 대한 영향을 조사하였다. YH3938과 YH3945는 발암원성 H-Ras에 의해 형질전환된 Rat2 세포의 증식과 형태 변화를 억제하였으나 K-Ras에 대해서는 효과가 없었다. N-Ras에 대해서는 약한 영향이 있었다. H-Ras와 N-Ras에 의한 SRE promoter 활성화는 YH3938과 YH3945에 의해 억제되었으나, K-Ras에는 영향이 없었다. Ras 단백질의 bandshift 분석을 통해 YH3938은 H-Ras와 N-Ras의 번역 후 변환을 억제하였으나, K-Ras에는 영향이 없었다. YH3945 는 H-Ras의 변환에만 영향이 있었다. 결론적으로 YH3938과 YH3945는 H-Ras의 farnesylation을 억제하여 그 발 암원성을 억제하며, YH3938은 N-Ras 작용을 농도의존적으로 억제하며, K-ras에 대해서는 영향이 없음을 알 수 있었다. 